\title{
On the Writing Style of Maupassant's Short Stories
}

\author{
Haijie Wang \\ School of Foreign Languages \\ China Three Gorges University \\ Yichang, China
}

\begin{abstract}
Maupassant's short stories are rich in subject matters, the ideas are novel and unique, the themes are profound, and the images are vivid. As the readers, we can see the truth in detail; the use of hidden art and the display of naturalism which are the main writing styles of his short stories.
\end{abstract}

\section{Keywords—Maupassant; short stories; writing styles}

\section{INTRODUCTION}

Short stories, with a small perspective to write small potatoes, carry both rich and diverse themes, at the same time, they require a perfect structure. How to achieve greatness in trivialness, that is, how to use the mortal matter of daily life to carry out their own artistic ideas? How to establish the relationship between characters? How the events and contradictions develop? Short story writers need to take into account all these problems. Under the tutelage of Gustave Flaubert, and influenced by Zola and Rousseau, Maupassant absorbed abundant nutrition from the French literature, he became a master of words and a skilled craftsman to plan the structure, so he skillfully unified the two kinds of artistic requirements and formed different artistic styles. After Maupassant was rid of Zola's naturalism, he retained naturalism as well as realism. He even tried to write various styles, including column, short stories, travelogues, psychological stories, short stories in the form of poetry and history, legends, science fiction etc. Therefore, the creation of Maupassant is not limited to any literary school, but he drawn lessons from them, and has provided a model for the later generations.

In Maupassant's whole lifetime, he wrote nearly 300 short stories, which were ingeniously conceived and had a tortuous plot. In his masterpieces, the picture of the human world is perfectly well depicted. Seeing reality in detail is the primary goal of Maupassant's pursuit of short fiction, it is also an important criterion for his realistic art of fiction. Maupassant mostly selected the daily life stories or scenes as his themes, which through a real, subtle, natural narrative art and descriptive art to attract the readers. In the description, Maupassant didn't even use the plot as a short scaffold and line. He has always cleverly strung up some believable little things with a very thin, much concealed, almost invisible clue. Maupassant's short stories are more interesting than traditional realism, and there is a new element of naturalism.

This paper is the program funded by Institute of Wuhan Studies (NO. jhunwyy2015351).
Despite the fact that Maupassant denies that he was a naturalism writer, but because he was in the prosperous era of naturalism literature ideological trend, he was deeply influenced by this kind of ideological trend, so he naturally took his realism art features of naturalism in his literary works.

\section{SeE THE TRUTH IN DetaIL}

To show the styles and features of that time, Maupassant described in depth the mundane life of some ordinary characters in the real world, or the daily trivialities that occur around ordinary people, which was one of his main writing styles. In his two hundred and sixty works, the personalities of the characters which he portrayed almost touched each social class and social stratum, such as the Normandy cunning farmers, generous craftsmen, bullied maid, small staff, small shopkeepers, ordinary citizen, the declined squires and businessmen, factory owners, as well as the ambitious politicians. For example, in $L a$ Parrure, the ordinary citizen who has ruined his life for vanity; In Boules de Suif, the rich merchant and the squire of the patriotic whore and the soft bones; in En famille, the family who fights for inheritance; In Deux Amis, two friends would rather die than tell the passphrase to the Germans, and so on. Maupassant described his attitude, thoughts and social ideals through a variety of characters.

Take Boules de Suif as example, there is no battlefield, there is no struggle. However, the depiction of the bitter experience of a prostitute who was forced to sacrifice to the enemy, highlights the ugly face of the proletariats for its own sake, as well as the regardless of national dignity. Boules de Suif was self-reliant and unyielding, showing the pride of patriotism, but she was thrown into the fire pit by the hypocritical countrymen. By means of the real details and subtle descriptions, Maupassant made the novel constitute a real social picture of the Franco-Prussian war in France, also reflect the author's hatred of the war, and the people's sympathy and disdain for the so-called gentleman.

In Deux Amis Maupassant depicted the patriotic image of two citizens in the siege of Paris. The author described the ordinary life of these two ordinary citizens in a large space, but it was such an ordinary person who would rather be thrown into the river and drowned by the enemies than reveal the password of the French outpost to them. In front of the severe ordeal, the two worms showed the national spirit and patriotism, the author praised the heroes and embodied his own patriotic passion in the meantime. 


\section{THE USE OF HIDDEN ART}

In Maupassant's short stories, the skillful use of hidden art is another important writing style. There is almost no factual and unimaginative narration in his works. At the same time, while artfully mastering how to hide, he also conveyed the reader's own views, which ultimately enlightened and educated the readers. This kind of hiding is not a real hiding, and he was just right to highlight the subject of the works, which is more intriguing than the plain and ungarnished narrative, and a long and tedious preach. The works of the Franco-Prussian War, such as Mademoiselle Fifi, Deux Amis, Boules de Suif, La Folle, Un coup d'état etc., their common characteristics are the use of simple language, simple structure, and the striking contrast, there are no complicated plot and profound theory. However, behind the seemingly simple plot, there is something thought-provoking.

The first is to hide the psychological activities of the characters. In order to capture the readers and impressed them, the author used some writing skills while he described the characters in the war. For instance, in order to highlight the central image, the works used a lot of sharp and powerful contrast-the evil foils the good and the ugly foil the beauty; for purpose of expressing his aversion of the war, Maupassant didn't write directly about the war, but elucidate obliquely the abomination of the people for the war with some trivial matters happened among the ordinary people. Citing Boules de Suif for example, the novel's protagonist is a prostitute, who is living in the lowest class of the whole society, and who represents the pariah and stigmatized status. Her presence seems to represent the fall of mankind and the darkness of society. Such identity, not only is scorned by the other passengers in the carriage, including herself, she was ashamed of her own identity. So when those arrogant lords and ladies, who have so hastily fled that forgotten to prepare food, were hungry, Boules de Suif humbly requested them to eat her delicious food. Here, the author naturally wrote the good nature of the protagonist, who did not have a fierce psychological struggle, neither any kind of pleasing depiction. Throughout the novel, there is no description of Boules de Suif's psychological activity; the author hid her happiness and joy, sadness and sorrow, pleasure and delight, injustice and indignation through the hidden art technique.

Then, it is the hidden technique of the visual image. American-born British great writer Henry James once said that Maupassant's vision was powerful, and he had a pair of sharp eyes which are enough to portray something unusual. In Boules de Suif, for instance, the author succeeded in using a series of contrasting methods that highlight the goodness and beauty of the protagonist. He didn't directly shape an image of beauty or ugliness, but depicted a group of vulgar and vile people to foil her beauty and kindness with the technique of hidden art. Also in this work, the people in the war were risking their own head, but Boules de Suif was very different from others.

It's still in this work, the author shifted the reader's vision to the food and clothing which were carried by Boules de Suif. The author did not account for the braveness and calmness of the protagonist, but she prepared adequate food and luggage, by this token, we are able to find that she escaped with full dignity. This didn't like those "respected" lords and ladies who were usually arrogant, aggressive, whereas the danger occurs, they exposed immediately their natural instincts, and became milquetoast, even forgot the food. Maupassant's unique vision, which hides the words and actions of every character, makes clearly the reader to distinguish the brave and the coward by the simple acts.

\section{Highlight THE NATURALISTIC FEATURES}

Naturalism is a tendency in literary and artistic creation. As a creative method, naturalism, on the one hand, excludes romantic imagination, exaggeration, lyric and other subjective factors. On the other hand, it despises the typical generalization of realism to real life, but pursues the absolute objectivity, advocates the description of nature, focuses on the real life of the phenomenon, and attempts to use the laws of nature, especially the laws of biology to explain human and human society. In the field of literature and art, the creative tendency of naturalism is to "follow the original things to imitate" as a starting point. Naturalism was born in France in 1860s and represented by Zola, who deeply influenced Maupassant both in thought and in creative methods. Maupassant's tutor, Gustave Flaubert, put forward the theory of "objective and apathetic", under the guidance of this theory, Maupassant pursues the realistic and natural narrative. This also makes his works just full with narrative stories, presenting pictures and depicting characters. It is very rare to think deeply about life and to explore some social, historical, philosophical issues by picturesque depiction.

The presentation of naturalism in Maupassant's works is firstly expressed by his pursuit of desire. In Un Mendiant, hungry for a few days, when the hero saw the flocks of chickens, "the mind had an idea, or rather it was his stomach who had a kind of feeling, that was to catch one chicken from the flock, and roast them on a fire, which is a heap of dead branches. It is probably tasteful to eat on the fire." As in Un Clochard, the writer wrote: "He felt hungry, it was a kind of bestial hungry, a sort of hungry which drive the wolf to eat people, and he carried the vague desire, just wanted to raise his arm and hit the guy who was the first to come home for dinner."

Secondly, the naturalistic features in Maupassant's works are mainly embodied in the description of love. In Le Baptême, the child's pure and innocent expression touched the Father's long held mind and made him unable to keep himself. At last, the child was raised as high as his face and kissed for a long time. In addition to this affection, the theme of love between men and women also occupies a large proportion in Maupassant's short stories. As in Miss Harriet, the author mentioned more than once the burning passion and the fiery sexual desire. In this crazy state, people listen to their instincts and desires, and only pursue the pleasure of lust. 


\section{CONCLUSION}

In his works, Maupassant faithfully inherited the tradition of critical realism, truly reflected the social life of France around $1870 \mathrm{~s}$, He exposed and criticized the various scandalous acts of society at that time, and had a high sense of value and artistic value. Among them, to see the truth in a subtle way, skillfully using hidden artistic techniques and highlighting naturalistic features are the main writing styles of Maupassant's short stories. In the ten years' creative career of Maupassant, he left a rich literary legacy for the world. Of all his works, the most prominent achievements were his short stories, which were the result of the writer's painstaking masterpiece. With his superb writing skills and his unique style of creation, Maupassant made us feel the inner emotion and the power of art.

\section{REFERENCES}

[1] A. Levy, The Nineteenth Century French Short Story: Language, Form and Ideology. London: History Press, 1995.

[2] A. Schmidt, Maupassant par lui-même. Paris, Seuil, 1962.

[3] A.S.Moger, "Narrative Structure in Maupassant: Frames of Desire", PMLA, vol. 5, p.45, 1985.

[4] C. Rougle, "Art and The Artist in Babel's Guy de Maupassant", Russian Review, vol. 3, p.25, 1987.

[5] D. Freimanis, The Paradox of Maupassant. New York: New York University Press, 1994.

[6] G. de Maupassant, Boule de suif. Paris: Folio Classique, 2014.

[7] G. de Maupassant, Oeuvres complètes. Paris: Arvensa Editions, 2013.

[8] G. de Maupassant, Une Vie. Paris : Librio littérature, 2013.

[9] L. Foley, Maupassant: Fifteen Tales. National Textbook Company, 1993

[10] Liu Mingjiu, Appreciation of Maupassant's Masterpieces. Beijing: China Peace Publishing House, 1995.

[11] P. Winn, "The Art of Rupture: Narrative and Duplicity in the Tales of Guy de Maupassant", South Central Review, vol. 6, p.132, 1999.

[12] R.Lethbridge, "Style and Vision in Maupassant's Nouvelles" , The Modern Language Review, Vol.84, No.4, p. 57, 2002.

[13] Robertson, A history of European Literature. New Haven, 1980.

[14] Wu Fuheng, A Review of Foreign Famous Writers. Jinan: Shandong Education Press, 1990.

[15] Yang Changlong: History of Western Literature. Xi'an: Northwest University Press, 1992.

[16] Yin Guangxi, Appreciation of Maupassant's Short Stories. Xi'an: Shanxi People's Publishing House, 1984.

[17] Zhang Guanhua, The Aesthetic Thinking of Naturalism. Chengdu: Chengdu University of Science and Technology Press, 1992.

[18] Zhang Yinglun, Eternal Meteor: Biography of Maupassant. Changsha: Hunan Literature and Art Publishing House, 1995. 